\title{
Languages and Postmodern Ethnic Identities
}

\author{
Livia Käthe Wittmann \\ University of Canterbury, New Zealand
}

Specific discourses of our mother tongue (which is not always our mother's tongue) are supposed to decisively constitute our subjectivity. These discourses which are constituting us and are available to us offer possible identities. These identities carry ethno-culturally-specific meanings, which are symbolised within and by spoken, written, and non-verbal language/s. Are languages given the same relevance when giving meaning to postmodern ethnicity, if one understands postmodern ethnicity as a "stance of simultaneously transcending ethnicity as a complete, self-contained system but retaining it as a selectively preferred, evolving, participatory system?" Multilinguality, as it may correspond with aspects of postmodern ethnicity, seems to imply an interaction between different languages with their distinct understanding of self and the world which manifests in a kaleidoscopic view, temporarily creating new constellations of meaning.

As we learn to speak, that is, to name, we also learn about identity/ies allocated to us and to others around us in childhood. The first language we learn, our so-called mother tongue, interpolates us not only into a linguistic but also into a socio-historic symbolic and concrete order. Our mother tongue then constitutes us by its manifold discourses whose totality is a specific symbolic order. This symbclic order, which embraces the dominant societal structures, produces by its very nature 


\section{Ethnic Studies Review Volume 23}

resistant forces and discourses to its established order as well.

Could one count among those resistant forces to an overarching symbolic system the same phenomenon when one's mother tongue is not one's mother's tongue? And what happens with that identity-constituting symbolic system when one is growing up bilingually or multilingually? George Steiner, who grew up trilingually, claims

I have no recollection of any first or bedrock language.

Later attempts to excavate one from within me, psychological tests, the hypothesis that the tongue in which I cried out to my wife when we were in a car mishap must be the linguistic base, have proved vain (even in moments of panic or shock, the language used is contextual, it is that of the speech-partner or locale). Whether it is in daily usage or mental arithmetic, in reading-comprehension or dictation, French, German and English have been to me equally 'native' (Steiner 1997, 78).

Steiner further maintains that even when dreaming the language in which he 'dreams' is circumstantial: he "simply dreams in the language in which he happen to have spoken that day." Would this statement imply that he feels at home equally in three symbolic systems? Steiner does indeed differentiate between the different symbolic orders or "worlds," as he calls them, constituted in and by the distinct languages. In his view

no two languages, no two dialects or local idioms within a language, identify, designate, and map their worlds in the same way. The memories stored, the empirical surroundings inventoried, the social relations which the language organises and mirrors (kinship, for example), [...] differ, often radically, from tongue to tongue. Immediately neighbouring tongues, even in the same climatic-geophysical locale, will differ to the pitch of total mutual incomprehension, (Steiner 1997, 87)

Is Steiner saying that although through each language one experiences oneself and the world in a different way, he is able to change from one to the other without difficulty? Would such a seamless changeover imply, in his case, the possibility of 
three performances of self, internally and externally, at variance with each other? To a certain degree I can imagine these performances, but only if the "performer" is able to alternate his/her living in all three-language environments for a similar length of time. Mostly this scenario is not people's lived reality. Mostly one's circumstances don't allow for such flexibility, and one of the language environments becomes the dominant symbolic from within which one operates. 1

Homi Bhabha's well-known dictum about living in interstices would be a different conception of dealing with the multiplicity in one's language/symbolic. Gloria Anzaldua's description of her living in and through different languages seems to be positioned between Bhabha's and Steiner's observations. Not all languages she learned to speak fit into the clear-cut framework Steiner was operating with, like French, English, and German. Anzaldua lists besides "standard English" and "standard Spanish" also "standard Mexican Spanish," "North Mexican Spanish dialect," "Chicano Spanish," "Tex-Mex," and "Pachuco" (Anzaldua 1986:55). Yet Anzaldua insists, not unlike Steiner, on the separateness and the autonomy of each of these linguistic systems. They all would then have their distinct symbolic order. "And because we are a complex, heterogeneous people, we speak many languages," claims Anzaldua, (Anzaldua 1986, 55).

What then is the crucial difference between Steiner's and Anzaldua's understanding of multilinguality apart from their obvious differences in the discursive constitution of their social, political, sexual, and historical self or identities? While Steiner still seems to believe in the possibility of positioning oneself through language performance in distinct worlds, Anzaldua writes against such conceptions by mixing languages within sentences. This forceful didacticism goes far beyond hitherto established literary practices. Reading Anzaldua's text it is hard to escape from realising her intention. It is about "Life in the Borderlands." And it is, beyond identifying with the historical vicissitude and hardship of the people known today as Chicanos, ("The New Mestiza") about the life of women who live within the borderlands of the Borderlands:

Alienated from her mother culture, "alien" in the dominant culture, the woman of color does not feel safe 
within the inner life of her Self. Petrified, she can't respond, her face caught between los intersticios, the spaces between the different worlds she inhabits. (20)

In the following I shall attempt to engage with the role of languages in ethnocultural identity formation with specific regard to the interviews conducted with Jewish women living in New Zealand.2 Three intertwined phenomena seemed to be of relevance: the ethno-linguistic specificities of minorities; the contradictions and ruptures of conceiving oneself and one's interaction with the surrounding world, and the realisation of the sex/gender specific divisions and allotments of the sociosymbolic. To look at them separately means simply to employ useful crutches for finding a path and temporary clearance in understanding.

The relevance of language in maintaining Jewish ethnoculture is well known. Indeed, as Benjamin Harshaw formulates it, Jews were in their "everyday awareness-as Jews-[...] connected to a universe of discourse, a 'fictional world' outside of history and geography, based on a library of texts and their interpretations." (Harshaw 1993, 21)3 ${ }^{3}$ He regards the function of Modern Hebrew of similar significance for the state of Israel, claiming that "it was not only that Hebrew was established by the young Yishuv, but Hebrew also established the Yishuv itself."4 (92)

Language has been regarded as one of the most important symbols of ethnicity. According to Joshua Fishman the three distinguishing features of ethnicity are signified with it and within it: descendency is recorded, customs and tradition explained and their meaning constituted with regard to understanding and interpreting oneself and the world one lives in. Because language has this complex function in constructing and representing ethnic distinctness, its symbolic value is often translated as the corpus mysticum of ethnicity itself (16). Indeed, as Fishman says, "...language is part of that corpus. It issues authentically from the body, it is produced by the body, it has body itself (and, therefore, does not permit much basic modification)." (16)

Why did I see the language issue as relevant when circumscribing Jewish identity in New Zealand? Specific discourses of our mother tongue (which is not always our moth- 
er's tongue) are supposed to decisively constitute our subjectivity. These discourses which are constituting us and are available to us offer possible identities. These identities carry ethnoculturally-specific meanings, which are symbolised within and by spoken, written, and non-verbal language/s.

What happens to bilingual or multilingual speakers? While the sociolinguistic theory of Joshua Fishman sheds light on the prerequisites for bilingual language maintenance (lasting minimally three generations), the potential differences in languagespecific meanings of identities are not dealt with. What Fishman explores is manifold in itself. He suggests that only if there are institutionally established separate domains for the maintenance of two (or more) languages is the survival of those languages (past three generations) likely to be ensured. One of his examples, which is for my study of special relevance, is the role classical Hebrew (Loshn-koydesh) plays in religious services of Orthodox Judaism. Since classical Hebrew has its institutionally secured domain in the religious service, it did and does survive.

Several questions arise: what potential contradictions are contained in the differences of discursive sexed/gendered identity formation offered by this function-specific Hebrew and the English vernacular of Jewish women living e.g. in New Zealand?

And for secular Jewish women does Modern Hebrew, as the national language of Israel, have a similarly symbolic function? If yes, again, what potential contradictions may arise between the sex/gender specific discourses for possible identities?

Yiddish will not survive in New Zealand past three generations. The women who spoke it in their childhood or youth will find no institutional domain, which could guarantee the survival of this language. Many participants remember only that their parents or grandparents had spoken it.

However for a number of the interviewees the mother tongue was either other than English or they could claim a variety of languages whose differing discourses offered multiple ways of giving meaning to the world. Mara's story is a good example for the implied complexity of living in different language environments and how it affects one's own changing 
positioning as a subject.

I was born in Poland where I lived until the age of five.

Then I moved to Russia where I lived till the age of twelve. Then, in Israel where I lived through my later childhood through to adulthood. That's where I went to school, to secondary school, to university and so on. I used to identify myself as Israeli but now I have been in New Zealand appreciably longer than any other country where I have lived before. In spite of my accent, would you believe I have been here for thirtytwo years? So I have stopped introducing myself as Israeli, but I definitely have a very, very strong consciousness of being one. I switched languages several times in my life. I switched from Polish to Russian to Hebrew." [After Hebrew she had to learn English.] Polish is the only language, which I speak like a Pole. But the Polish accent has stayed with me and overlays every other language I speak.

When asked in which language she is able to express herself best, Mara says:

It would have been Hebrew, but not any more. It's there, it's latent, it's dormant. If you don't use a language you forget it, it goes rusty. My active vocabulary lags behind my passive one. So I must say that the language in which I express myself with the greatest ease is English. But I still count in Polish. Counting somehow, even if I forget Polish altogether, counting still stays in the language in which it was first learned. It's almost reflexive. There are things I want to express in Hebrew because Hebrew was the language of my really important years between twelve and twenty-four. I went back to school in Israel, to secondary school, to university and then served in the army for two years. I was Israeli. I was developing while the Hebrew language was developing because the Hebrew language was developing at great speed, taking the old language from the Old Testament, from the Bible but of course building lots of new words which weren't in the Bible, and abstract terms. So I really grew up with Hebrew because I was the gener- 
ation which was growing up during the war of Independence.

Mara claims that she expresses herself at present with the greatest ease in English and that her Hebrew became dormant. What would be the ramifications for the way in which her self, identity, identificatory modalities were constituted in the discourses of the Hebrew language? Did they become "dormant" as well, or did they become part of the complex process of postmodern ethnic identity? Are languages given the same relevance when giving meaning to postmodern ethnicity, if one understands postmodern ethnicity as a "stance of simultaneously transcending ethnicity as a complete, self-contained system, but retaining it as a selectively preferred, evolving, participatory system?"5

Mara's family belonged to "assimilationist" Polish Jews who constituted, according to Celia Heller, one-ninth to onetenth of the Jewish population in Poland, which numbered over three million before the Shoah (Heller 1977, 188). These Jews were to have differed from the rest of the Jewish population not only in their degree of acculturation (Polonisation) but also in their conscious self-identification as Poles. Mara remembers that she had only learned that she was Jewish after the Germans invaded Poland. So Mara's first language or mother tongue was Polish. She still counts in Polish, the language in which she obviously first learned to count. Counting is indeed a give-away of one's first language/s because the mechanism of memorising in the learning process retains its functioning and springs to life beneath the surfaces of subsequent, later learned languages.

Mara acquired Modern Hebrew, one of the signifiers of symbolic ethnicity, only in her youth when she attended secondary school in Israel. Her example tells a cautionary tale about crediting the mother tongue with ethnic authenticity. Fishman gives a very different example when warning of making general assumptions regarding the ethnic authenticity symbolised by the mother tongue by drawing attention to the fact that Yiddish, although the mother tongue of generations of Ashkenazi Jews for centuries, has its origin in a non-Jewish language, namely in German.

Regarding Mara's case: Polish is her mother tongue but 


\section{Ethnic Studies Review Volume 23}

this mother tongue has no association with her Jewishness. Is Polish then a symbolic marker of a Polish ethnicity? Let me examine this question further.

Fishman, as referred to above, distinguishes three identifiable features of ethnicity: paternity, patrimony, and phenomenology. This terminology, as useful as it may be in certain ways, also highlights an unselfconscious androcentrism producing absurdities. How can the mother tongue signify "paternity"? And further, since for Jews descendence is acknowledged through the mother, how can it be then called paternity? This semantic confusion throws light upon the power factor within the ethnic discourse and the discourse on ethnicity.

Fishman calls "patrimony" a dimension of ethnicity, which relates to the issue of how ethnic collectivities behave to express their membership. Language is also an important element of patrimony because it is recognised as a guide to "kinship-interpreted group membership," as a desideratum and demonstration of such membership. As referred to above, Fishman claims: 'Language is among the conscious 'do' and 'don'ts' as well as among the unconscious ones, that is among the evaluated dimensions of ethnicity membership (whether consciously or not) (Fishman 28).

Fishman calls "phenomenology" the meanings that one attaches to one's descent-related being and behaving. He claims that one's ethnicity views inform one's views of history, of the future, of the purpose of life, of the fabric of human relationships. And

since ethnicity often deals with very powerful, presumably irreducible, beliefs, feelings and bonds, it is all the more likely to be importantly related to allembracing ways of viewing, to Weltanschauungen, to cosmologies. Since ethnicity is often part of a collectivity's highest (or deepest) cultural symbolism, a symbolism that is holistic and that serves profound integrative functions, it is vital that we grasp these meanings, for in doing so we are likely to grasp something truly vital not only about ethnicity, but about society or culture as a whole. .... Ethnicity is the 'cup of custom' (patrimony) passed on by one's parents (paternity), from which one drinks the meaning of 
existence ... through which one envisions life (phenomenology) (30-31).

How would Fishman's categories help to define and clarify Mara's ethnocultural identities with regard to the relevance of languages in her life? Polish was her first language and, as she says, "the only language which I speak like a Pole." Would that mean that Polish is the only language of Mara's which can function as a symbolic marker of ethnic belonging? The contradiction between theory and practice in this case necessitates a revision of Fishman's observation about the main function of the mother tongue in defining one's outlook on life embedded in ethnicity. Indeed, one ought to make the connection to Fishman's view on postmodern ethnicity (18) reflecting a contemporary situation and very much that of diasporic conditions.

The most cherished and significant language in Mara's life, according to her own evaluation, is Hebrew. Modern Hebrew. Not only because she spoke it between the age of twelve and twenty-four which she calls the most important years in her life, but also because Hebrew as a vernacular became the language of Israel, a country (and nation-state) to which Mara belonged, whose citizen she became consciously and committedly: "I was Israeli." Indeed she draws a parallel between her own growing awareness of herself and the world around her and the development of modern Hebrew: "I was developing while the Hebrew language was developing." It was then Hebrew as a vernacular through which Mara learned to give meaning to the world. Her Jewishness became one with her Israeliness, an overlap of ethnocultural and national identities.

Mara has now lived for more than thirty years in New Zealand. The language in which she now expresses herself with "the greatest ease" is English. Her Hebrew became "dormant"; her active vocabulary lags behind her passive one, as she puts it. Her everyday life is conducted in English. Since Mara's husband is a New Zealander they speak English in the home. At her workplace, in her neighborhood, within institutions she has to deal with, it is the English language she has to use. In addition Mara was eager to acquaint herself with the culture of the country she was living in; as she says:

I am a tremendous book-lover, a very dedicated read- 


\section{Ethnic Studies Review Volume 23}

er and I believe that you can learn a lot by knowing people of a certain culture but there is a limit to it. Usually you will know people only from a certain circle. Therefore, I think a wonderful way to get to know a culture is from reading the literature of the country. I don't mean non-fiction, I mean real literature. I have observed New Zealand culture quite a lot. I think I know quite a bit about New Zealand culture. I have lived it for thirty-two years, I definitely identify with it and having brought up three children and being married to a fourth generation New Zealander there is no escape from it.

Fishman calls this process language shift. Mara's children were born and grew up in New Zealand, an English speaking country; their mother tongue is English. Mara herself is not only multilingual, she embraces multiculturality by choice but also by historical necessity. The three features distinguishing ethnicity in Fishman's terms would, in Mara's case on the individual level, most probably constitute a postmodern ethnic identity. This postmodern ethnic identity has to be imagined as a process. It is not so much an interaction between distinct ethnocultural identities, but rather it would consist of gradual changes, as the socio-cultural and political discourses of the dominant ethnolinguistic collectivity (white middle-class New Zealanders) would pervade and alter formerly established value systems and understandings. I imagine this process as preliminary clashes between value-systems, which deeply affect one's formerly created conscious and unconscious identities. Gradually the clashes, experienced often as violation of one's subjectivity, may give way to a kind of amalgamation and fluidity in one's construction of self and one's Weltanschauung. By this process I mean to indicate not so much a smoothness of the occurring changes through interacting as an ethnic minority individual with an ethnolinguistically and culturally different majority collectivity, as a kind of negotiation and permutation. As a result there may be areas retained with their 'original' emotive and sometimes cognitive attachment, and there will be other areas which undergo profound changes. 6

An example for me of what I mean by "areas retained for their 'original' emotive and sometimes cognitive attachment' is 
how Mara regards Polish and Hebrew. She says:

Language colours your thought processes so much and words in certain languages carry such different connotations. If you say river to me in Polish, I don't see just water, I see a little child playing in her summer beachsuit. I see the clear pebbles, I hear the sound of the river, I hear the splash, I feel the touch of putting my foot in the water. From childhood, because that's what river meant to me then. If I say it in English or Hebrew it's just a technical word.

The study of the Bible was a core subject for UE,7 it was compulsory. We had to study the Bible but we studied it from a linguistic point of view, from a historical point of view, from a literary point of view. The poetics of the Bible in Hebrew are wonderful, the richness of the language. .... Because I learned Hebrew from this poetic, literary, historical point of view and not pure religion it has fired me tremendously. So, for me Hebrew is poetry.

Changes or rather interchanges may occur in areas where adaptability (not always and not necessarily consciously) would secure a certain degree of acculturation. This can take place on a cognitive (and perhaps also emotive) level of giving meaning to the world, but it can also take place on the level of performative interaction with others, whether within institutions and organisations or within social encounters. The process character of one's discursive positioning as a subject becomes more tangible for ethnic minority people for whom the above mentioned changes are part of a language shift. Eva Hoffman devoted a whole book describing ethnocultural changes experienced when as an adolescent she underwent the trauma of leaving her native Poland and having to adapt the to language and other features of a new ethnoculture/s in Canada. The title of her book, Lost in Translation, indicates the impossibility of transferring one's subjectivity from one set of discourses in one language (Polish) into another set of discourses in a new language (English). One has to change in one's interaction with others, suggests Hoffman, or one would remain unintelligible. 8

Another area where ethnocultural identification may take place and where meaning is created through language is liter- 


\section{Ethnic Studies Review Volume 23}

ature. I was interested in whether the women interviewed for my study were reading books specifically by Jewish authors or not, and if yes, what their motivation was for it and what enjoyment they got out of such texts. I assumed that it would give me an indication about aspects of Judaism, Jewish history, Jewishness, which the women would find appealing or relevant. Mara's answer to the question whether she is reading literature by Jewish authors was the following:

Yes, but not consciously. Recently there was a book sale and my daughter and I went and rummaged around. I bought this and that and I bought it purely because I had read the author before, or the blurb made me think it would be my cup of tea, or by word of mouth recommendation. When we got home my daughter said, "do you realise that every single book you have chosen is something to do with Jewishness?" And it took me by surprise, you know. It was either a Jewish author, or a Jewish character or some Jewish connection and it was utterly unconscious or subconscious. Utterly non-deliberate choice from a Jewish point of view.

Asked, what she enjoyed about reading Jewish literature, Mara responded:

I like the gutsiness. I come from an emotionally anaemic family [secular Jewish family]. Things for them were just so and nobody went around flailing their arms, madly happy, or madly unhappy. Things were kept 'in good taste'. When I read Jewish literature, I think oh God, I don't think I could have survived in a family like this. But I love the emotional charge of Jewish families, utterly neurotic and utterly mad and maddening but here is part of my Jewishness. When they scream at each other they scream, stereotype perhaps, but I think it's the gutsiness that appeals to me.

I strangely enough enjoy Jewish literature which is about religious families because it's an aspect which I don't know first hand and therefore it's like peeping into an unfamiliar world.

What seems significant to me about Mara's answer is her 
unconscious but also conscious need to find out about aspects of Jewishness and Jewish life which she had had no part of. In her past she especially emphasises the appeal of emotional interaction among Jews and also her interest in gaining insight into the life of religious families as created within fictional reality. It is exactly that part of Mara's ethnoculture of which she had been 'deprived' according to her own observations. By wanting to find out more about neglected or unrealised elements of her Jewish ethnicity (which belong to "patrimony," the ethnocultural ways of behaving, the customs), Mara engages with them in a very intimate and private way. It is however an engagement, and an active one, since reading is always an active encounter between reader and text. It is only through the reader's active involvement with the text that fictional reality comes into existence. And as our interest, empathy, and level of engagement will be always at variance with the constructed reality of books, the worlds of our identifying imaginations/fantasies will also differ. This process is not crucially different from our "understanding," that is, for our creating our lived reality. Our giving meaning to the world at large or our 'belonging' to any wider or closer cultural, political or ethnic community is as much based on what we want and need to believe as it is based on "objectively" measurable aspects of membership and interaction with others claiming the same membership.

Reading literature can additionally function as a source of knowledge. When Mara is reading about the joy and sorrow and their expression in religious Jewish families in the intimate space and timeframe of her encounter with them, she might not only follow and identify with the emotions of the fictional characters and the events which generated them but gain some knowledge about the premises of their existence.

However there is one crucial factor which should not be overlooked when acknowledging the relevance of fictional (and other, where it applies) literature for the women in affirming their Jewish identification. It is an andro-logo-centric worldview, which characterises the novels and short stories of the Jewish and Yiddish writers referred to in the interviews. The authors mentioned most were Bernard Malamud, I.B. Singer, Sholem Aleichem, Shalom Asch ana Chaim Potok. The one female writer, who seemed to be popular with many of the 


\section{Ethnic Studies Review Volume 23}

interviewees, Bernice Rubens, is hardly an exception to the gender-biased narrations of the above listed authors. By gender bias I don't mean a necessarily overt sexist construction of female figures within the world of fiction but the use of traditionally established clichés of women in their psychosocial and sexual functions. Although such literary projections of male fantasy may have their Jewish variation, they don't challenge in any profound way the basic construction of woman within the dominant male discourse which has the threesome variety according to Luce Irigaray: to conceive of woman as the opposite, the complement, or the same as (the unproblematic) man.

Kate, the other Israeli woman who participated in the interviews, seems to confirm this understanding of the written text. She says

I love reading. In Israel I read a lot. I read for pleasure and in English it's a lot of hard work but I do want to educate myself to read because I think it's important. I think books are the key to knowledge.

Kate belongs to a younger generation of Israelis than Mara. She was born in Israel. She had the good fortune of having her parents immigrating to Palestine before the Shoah. Although her first language is modern Hebrew, she has doubts whether it is her mother tongue because her mother's 'tongue' was Yiddish, which she, however, did not pass on to her daughter. l'll quote the whole passage in which this information is couched. It is Kate's response to the question of what Hebrew means to her:

That's the native tongue of the Israeli people. I think when you look at the Jewish people, those who came from Europe, many of them brought Yiddish with them. From the Spanish part they brought Ladino. When you talk about Hebrew, Hebrew and New Hebrew is the clear thing about the Israeli people definitely, it's their native language. Not exactly my mother tongue because when my mother wanted to speak and for us not to understand she would speak in Yiddish. I don't speak it; my mother never bothered to teach us. I think Yiddish is a very juicy language and it's a foreign language. It's a combination of German 
with Jewish emphasis in it. You wouldn't want it as a national language; you'd want Hebrew. There was the old Hebrew but I think a lot of things had to be renewed in the old language. Modern Hebrew is a new language. When I go to Israel there are things l've never heard because the language is coming along all the time. Even the slang, because I haven't lived there since I was twenty-three, you miss out.

There are significant similarities and differences between Kate's and Mara's ethnic "paternity," for neither constitutes their mother's first language, their own mother tongue. But for both modern Hebrew is the symbolic signifier of a strongly felt national identity. This national identity takes priority over ethnic identity. They both claim to be Israeli first and Jewish second. The identification with the discourse of nationalism with regard to the state of Israel seems to have formed more crucially their positioning regarding a collective identity than the historic tradition of Jewishness. The issue of Jewish identity in all its possible manifestations became a diasporic phenomenon.

Most of the women who participated in my study have been to Israel at some time in their lives or had been living there for months or years. For some women going to Israel in their youth became part of their search for the meaning of their Jewish identity; for others visiting Israel means maintaining the link with other family members, and for some others again, it seems to be a need later in life to reconnect with the country of symbolic belonging. What part does the knowledge of the official language of the country, modern Hebrew, play in this symbolic belonging? For Jews in the Diaspora attending the synagogue, especially in orthodox congregations, knowledge of classical Hebrew (loshn koydesh) is a prerequisite for participating actively in the religious service. And there is Yiddish, the vernacular of Ashkenazim in the past, which still figures as an element of Jewishness in the narratives of many of the older women.

One of the aims of my research was to find out how far Hebrew and Yiddish were functional in generating an "authenticity" of ethnocultural identity. But also, what could be the domain of these languages for women living in a dominantly English speaking country like New Zealand? Further, how do 


\section{Ethnic Studies Review Volume 23}

Hebrew and Yiddish interact with other mother tongues and languages? And how do the women who were not born in New Zealand create and re-create their ethnocultural identities?

If Jewishness is regarded as an ethnicity, how does this ethnicity interact with the participants' other ethnicities? How do different languages as symbolic markers of subsequent ethnocultures interact in constituting one's multiple identities or one's postmodern ethnic?

My focus here is on the function of languages in creating ethnocultural identities. Within the languages relevant for the interviewees I can only surmise certain dominant discourses crucially affecting identificatory processes. It is the discourses, embracing customs, traditions and gender-specific ways of giving meaning to life within their discursive fields in any one language which contain the identificatory differences between people belonging to specific ethnocultures but also among people belonging to the same ethnicity.

Looking at the term ethnicity Fishman comes to define it as a historical process:

Ethnicity is not synonymous with all of culture, being merely the aggregative definitional dimension thereof, the overlap between the two being a function of societal modernization. At earlier stages of societal development, ethnicity tends to a greater overlap with culture as a whole and there are ethnic ways of dressing and building, ploughing and curing, worshipping and fighting, engaging in commerce and engaging in art, sports or study. Ethnicity may be less conscious but more pervasive. In more modern life, ethnicity retreats into a corner of social experience under the impact of international influences (influences whose ethnic origins are unknown or overlooked, and widely accepted across national boundaries), but, perhaps precisely therefore, it is often rendered more conscious and is more manipulated as a boundary mobilization mechanism. (Fishman 6)

Fishman concurs with theorists like Homi Bhabha when he elaborates on the permeable nature of ethnicity. As early as 1977 he talks about "postmodern ethnicity" for which he allows a lack of fixity. He compares this lack of fixity or rather inter- 
active openness of ethnicity favourably with the hierarchical and rigid nature of racism and nationalism:

Characteristic of postmodern ethnicity is the stance of simultaneously transcending ethnicity as a complete, self-contained system, but of retaining it as a selectively preferred, evolving, participatory system. This leads to a kind of self-correction from within and from without, which extreme nationalism and racism do not permit. (1989:18)

What is being retained and what can change within one ethnicity by interacting with others? Are there within any ethnicity or ethnoculture distinguishable features which are more or less sensitive to possible changes? Are some features more constant and others more changeable? And where does the ethnoculturally most distinguishing feature of language fit in?

What Fishman calls "paternity" deals with "the recognition of putative biological origins." It refers to descent-related heritage like mentality. The kinship metaphor is often used which then can be extended to ethnic collectivities: the search for historical roots.

Through common, distant ancestry ethnicity experiencing individuals and collectivities gain a feeling of continuity, a sense of permanence across time, across death, from eternity to eternity. Through ethnic collectivities individuals feel augmented and come to experience immortality as an immediate physical reality. (26).

Because language is so often taken as a biological inheritance, its association with ethnic "paternity" is both frequent and powerful. Language then becomes the symbolic signifier of ethnicity. To speak a certain language is supposed to lend ethnic authenticity to the speaker. But only if it is her mother tongue. To this kind of ideology responds Hélène Cixous in her book, Coming to Writing, when she claims: "I have no legitimate tongue. In German I sing; in English I disguise myself; in French I fly, I thieve. On what would I base a text?"(Cixous $1991,15)$ Fishman himself allows for cases where language can't be regarded as symbolic signifier of ethnicity. My own research confirms this, as with the above-introduced case of Mara. It may be of relevance here to cite Hélène Cixous' observations on the effect of languages-mother tongue and oth- 


\section{Ethnic Studies Review Volume 23}

ers-on one's understanding of self and the world. She engages with a phenomenon to which more and more people could relate in recent times. There are features in her multilinguality which seem to overlap with those of the formerly quoted George Steiner and others which differ in circumstance and interpretation markedly from his. Cixous' background of childhood and language learning was in her wider social surrounding French and Arabic spoken in Oran, Algeria, although, as she asserts: "I felt that I was neither from France nor from Algeria. And in fact, I was from neither." (Cixous 1991, xix) At home her mother and grandmother, who were refugees from Hitler, spoke German; her father's family, who came from Morocco, spoke Spanish at home. Cixous' father himself taught his daughter French, Arabic, and Hebrew. In school she learned English. Despite these languages Cixous remembers that in Algiers, where the family moved after the war, she "didn't belong to the European community and wasn't admitted into the Arab community, [she] was between the two, which was extremely painful." (Cixous, 1991: xx)

About the significance of the various languages for her Cixous reflects in a way which retains some of the mystical qualities of the so called mother tongue which is meant here as literally the mother's tongue, combining it with a critical analysis of the socio-political meaning the other languages gained for her. The whole contemplation is couched in a poetic discourse. "I was raised on the milk of words. Languages nourished me," writes Cixous. (Cixous 1991, 20) The metaphor, "milk of words," plays on the association 'mother's milk,' the first nourishment, which then turns into the half abstract, half concrete concept of languages. Her description of the inseparable unity of body and mind is not imaginary but becomes a surprising factuality:

I hated to eat what was on my plate. Dirty carrots, nasty soups, the aggression of forks and spoons. 'Open your mouth.' 'No.' I let myself be fed only by voice, by words. (Cixous 1991, 20) ${ }^{9}$

The voice Cixous refers to is spoken in German. Therefore she writes a few paragraphs later: "My German mother in my mouth, in my larynx, rhythms me." (Is this rhythming not reminiscent of Kristeva's semiotic/motherly rhythming? ${ }^{10}$ ) 
Cixous distinguishes between the language/s she speaks and the ones she writes. She names German her mother tongue as most influential for her own speaking voice because it was in fact her mother's first language and the one she perceived first:

In the language I speak, the mother tongue resonates, tongue of my mother, less language than music, less syntax than song of words, beautiful Hochdeutsch, throaty warmth from the north in the cool speech of the south. Mother German is the body that swims in the current, between my tongue's borders...(Cixous 1991, 21-22)

Note that for Cixous, however, "In the language I speak" is French. French is also the language in which Cixous has written most of her works so far; after all she does live and teach in France and has done so since 1955 from the age of eighteen. So then what was the function of the German language for Cixous' ethnocultural identity? It seems not more than the reason for being always aware of a foreignness but in a constructive, challenging way, since it prohibits any kind of fixity, "the agitation that will not allow any law to impose itself." (Cixous $1991,21)$ If one accepts the axiom that language shapes reality and is, in turn, acted upon by local human experience, then for a multilingual creation and understanding of the world there can be only multiplicities of reality. In Cixous' formulation

Blessing: my writing stems from two languages, at least. In my tongue the 'foreign' languages are my sources, my agitations. 'Foreign': the music in me from elsewhere; precious warning: don't forget that all is not here, rejoice in being only a particle, a seed of chance, there is no centre of the world, arise, behold the innumerable, listen to the untranslatable. [...] Languages pass into my tongue, understand one another, call to one another, tenderly, timidly, sensually; blend their personal pronouns together, in the effervescence of differences. Prevent 'my language' from taking itself for my own: worry it and enchant it. (Cixous 1991, 21)

The above quote makes it clear that Cixous sees only the benefit of multilinguality, since it prevents a one-sided or 


\section{Ethnic Studies Review Volume 23}

myopic view of the world. Steiner interprets his tri-linguality in equally positive terms and suggests that his polyglot matrix was far more than a hazard of private condition. It organized and imprinted on his identity the complex and resourceful feeling of Central European and Judaic humanism. "Speech was, tangibly, option, a choice between equally inherent yet alternate claims and pivots of self-consciousness. At the same time, the lack of a single native tongue entailed a certain apartness from other French schoolchildren, a certain extraterritoriality with regard to the surrounding social, historical community." (Steiner 1998,121) Steiner claims a kind of mutuality in suspicion of the "other," because to the "many-centred", as he calls the multilingual/multicultural speakers, "the very notion of 'milieu' of a singular or privileged rootedness is suspect." (Steiner 1998, 122) Narrowness versus openness? Or perhaps restricted versus wider knowledge base?

Cixous makes the distinction between the dominant discourses in different geo-political language environments as they came to affect her conception of self. She recalls how she saw herself and how she was seen in Algiers by having French nationality and how the emphasis of self-conception changed when coming to live in Paris where the dominant discourses were less anti-Semitic but more phallocentric:

The logic of nationality was accompanied by behaviours that have always been unbearable for me. The French nation was colonial. How could I be from a France that colonized an Algerian country when I knew that we ourselves, German Czechoslovak Hungarian Jews, were other Arabs. I could do nothing in this country. But neither did I know where I had something to do. It was the French language that brought me to Paris. In France, what fell from me first was the obligation of the Jewish identity. On one hand, the anti-Semitism was incomparably weaker in Paris than in Algiers. On the other hand, I abruptly learned that my unacceptable truth in this world was my being a woman. Right away it was war. I felt the explosion, the odour of misogyny. Up until then, living in a world of women, I had not felt it, I was Jewess, I was Jew. (Cixous, 1997:204) 
Cixous developed first her feminist discourse, which shared its driving urgency with the writings of Irigaray, Kristeva, and other women in France. The significance of Jewish identity as part of the driving force manifest in her writing surfaces later but not separately from her feminist critical theory. It is in her above quoted books, Coming to Writing, and Rootprints, that the relevance of her Jewishness as an organic part of her writing, that is creating meaning in and through language, gains pertinent expression.

For Irena Klepfisz the Yiddish language itself has to become the carrier of her "secular Jewish identity." (Klepfisz $1989,32)$ I find her attempt to achieve this highly successful because not only do the title and the bilinguality of her renowned poems in the cycle, Di rayze aheym/The Journey Home, embody the intention of the author whose language of living and writing is foremost English, but these texts affect the reader in an additional way. They succeed in teaching the reader the Yiddish words and phrases through the way the poems are constructed. The English translation of the Yiddish elements forms one part of the dialogic structure. Klepfisz engages both languages, English and Yiddish, with each other, in a way which marks her own "journey home," to the Jewish past, to Yiddish as the "mame loshn" of her ancestors. The reader participates in this journey by learning the Yiddish words and phrases as they are repeated in English and again in Yiddish to form the interaction between past and present. I shall quote here the last two pieces of the cycle, 8 and 9, which illustrate the problematic and the method of its solution.

\section{Di Tsung/The Tongue \\ Zi shvaygt. \\ Di verter fein ir \\ she lacks the words \\ and all that she can force}

is sound

unformed sound:

a

der klang

the sound 
Ethnic Studies Review Volume 23

0

das vort

the word

u

di tsung

the tongue

o

dos loshn

the language

e

di trern

the tears.

9. Di rayze aheym/The journey home

Zi flit

she flies

vi a foygl

like a bird

vi a mes

like a ghost

$\mathrm{Zi}$ flit

iber di berg

over the mountains

ibern yam

over the sea.

Tsurik

tsurik back

back

In der fremd

among strangers

iz ir heym

is her home.

Do

here

ot do

right here

muz zi lebn

she must live.

Ire zikhroynes 
her memories

will become monuments

ire zikhroynes

will cast shadows.

For Klepfisz the "journey home" through the Yiddish language originates, indeed, from another (language) place. It is not the search of what one left behind but the desire to gain what one never had. In other words while Steiner and Cixous, and in another way Anzaldua, contemplate the significance of the symbolic order manifest in and through the different language environments they live in and languages they speak, Klepfisz argues for the revival of Yiddish as a means of ethnic revival, which translates itself for her to maintaining Yidishkayt (Yiddishness). However Yiddish is for Klepfisz a language she learnt as an adult; it was neither her mother tongue nor did it belong to the languages of her early childhood. She remembers:

Yiddish was not my mame-loshn. Because I was born during the war and my mother and I were passing as Poles, Polish became my first language. I began hearing Yiddish only later in Lodz, though in the first kindergarten I attended, I began to write Polish. In 1946, my mother and I immigrated to Sweden, where we lived for the next three years. I attended school and learned to read, write, and speak Swedish. At home, I continued speaking Polish though I heard and understood the Yiddish of the other DPs living in our communal house. And then we came to America. I began speaking English and ever so slowly, over the years, started to think, to dream in English. Eventually English was the language I spoke with my mother. (Klepfisz 1989, 33)

Klepfisz became confident enough in the English language to introduce bilinguality into her poetry. This poetry has a readership in mind which could or would respond to the interaction of English and Yiddish in a variety of ways, emotionally, with intellectual or aesthetic appreciation. Yiddish corresponding to English and the other way around also generate satisfaction and awareness of a political nature bearing in mind the histor- 


\section{Ethnic Studies Review Volume 23}

ical relevance of both languages. The assumption in Klepfisz' text for both languages and the socio-symbolic they represent is that they would have a readership which was able to follow different ethnocultural significations. In other words Klepfisz can count on readers who, beyond being at home in English, either understand Yiddish and/or appreciate the cultural and historical memories which resonate in and are evoked by the words.

Klepfisz' clearly stated intention is to revitalise the Yiddish language. Very different indeed is the aim of a number of memoirs written by Hungarian Holocaust survivors. (Suleiman, 1998) They are not professional writers and live as emigrants in countries with a "foreign" tongue. Suleiman refers to memoirs written between 1978 and 1993 in English and French, languages which the authors had learned as adolescents or adults since living in that new language environment. The autobiographical accounts of these Hungarians illustrate according to Suleiman, that they are reader-friendly in their use of language:

they generally keep foreign words out (or gloss them if they must use them), try no experiments in polylingualism, and opt for traditional forms of narration, description and dialogue. [...] At the same time, they are all marked as "foreign" to the non-Hungarian reader by the presence of unassimilable linguistic elements, namely, an abundance of Hungarian proper names. (405)

What is interesting for me is what Suleiman writes about her reaction to these Hungarian proper names. Although she acknowledges that some non-Hungarian readers "may dream over the proper names precisely because they are foreign," for her, a Hungarian by birth, some of the names lend themselves to "decipher" hidden stories of their bearers:

Magyar and Mosonyi are 'Hungarianized' family names, signs of patriotism and a middle-class desire to assimilate, typical of educated Hungarian Jews to this day. [...] Dawidovitz, Glück, and Klein, by contrast, are names that fit the modest lives of the religious rural Jews who bore them, and who often spoke Yiddish as a first language (generally, they spoke Hungarian as well) (408). 
While the meaning attached to name changes may share a commonality with similar assimilatory practices of Jews living in other countries, the referential reading for Suleiman of especially Hungarian first names would be most probably shared only by Hungarian speakers like Suleiman and myself. What works for her, writes Suleiman,

is not the referent but the signifier because names/signifiers like Szombathely and Tolcsva signify Hungary, as Dezsö and Imre (and Laci, Miklós, Ernö, Pista, Géza, Bandi, Jenö, and Béla) signify Hungarian men, and Manci, Joli, Rózsi, Magda, Marika, Ibolya, Évi, Zsuzsi, [...] signify Hungarian women. But it is not today's Hungary or today's Hungarians that these names evoke most vividly: to go to Szombathely is not my desire. (I have been to Nyiregyháza, my mother's birthplace-once is enough.)(410)

What may be the pleasure that these signifiers generate, beyond the satisfaction that Suleiman (and I) know how to pronounce these names according to the Hungarian phonology? For Suleiman

A name written down, pronounced, can suddenly revive a forgotten or dead person not only for the writer who remembers the name, but also for the 'autobiographical reader' who associates a different person or group of persons with the name: the signifier, being identical, 'floats' over to cover the shifting referent. [...] The name resurrects the lost objects, but at the same time reinforces the sense of their pastness, their goneness. These people, these places (as they were, towns with many Jews in them) no longer exist. (410)

The Hungarian names within the context of these Holocaust memoirs may represent a last concreie trace in language of the symbiosis of Jewish-Hungarian ethnocultures as it existed once, before the Shoah.

For Franco-Maghrebians like Derrida, language, signifying a belonging by birth, which can be referred to if even only by evoking it in names, doesn't exist. For him, as he claims, there has been always only the monolingualism of the other (Derrida 1996). As he begins to elaborate on the topic he posits a chal- 


\section{Ethnic Studies Review Volume 23}

lenging statement: "I only have one language; it is not mine."(Derrida 1996, 1) How is this to be understood?

Derrida leads his readers back to the history of the Jews in Algieria: they were given French citizenship in 1840, but it was taken away from them by Pétain's government in 1940. Although the period of being deprived of citizenship lasted for the Algerian Jews a relatively short time, three years, its significance remained lasting. Derrida explains this with the "disorder" that had been created through this act for FrancoMaghrebien Jews' understanding of their identity. He writes:

I was very young at that time, and certainly did not understand very well-already, I did not understand very well-what citizenship and loss of citizenship meant to say. But I do not doubt that exclusion-from the school reserved for young French citizens could have a relationship to the disorder of identity ... I do not doubt either that such "exclusions" come to leave their mark upon this belonging or non-belonging of language, this affiliation to language, this assignation to what is peacefully called a language (Derrida 1617),

Leading to the heart of the matter Derrida verifies the psychoanalytic insight that the I in any "autobiographical anamnesis presupposes identification" (Derrida 28). In contradistinction to identity which Derrida claims is "never given, received or attained", the "interminable and indefinitely phantasmatic process of identification endures" (28). This identification process or "identificatory modality," always occurs in language; in fact, as Derrida argues, it must be "assured" of language, since it is in language that "all the models and identificatory modalities" are contained. He claims:

It is necessary to know already in what language $I$ is expressed, and I am expressed. Here we are thinking of the I think, as well as the grammatical or linguistical I, of the me [moi] or us [nous] in their identificatory status as it is sculpted by cultural, symbolic, and sociocultural figures. From all viewpoints, which are not just grammatical, logical, or philosophical, it is well known that the I of the kind of anamnesis called autobiographical, the I [je-me] of I recall [je me rappelle] is 
produced and uttered in different ways depending on the language in question. It never precedes them; therefore it is not independent of language in general (28-29).

The point Derrida is making is that although he learned in French to say I and me, the assurance of this process was taken away from him in childhood as he relates it in the formerly quoted passage referring to the years between 1940 and 1943 when his French citizenship was taken away, and he was excluded from schools for French citizens. ${ }^{11}$ However to learn other languages like Arab, Berber, or Hebrew, although not prohibited, certainly was not encouraged in his years at the lycée in Algiers. The language through which he had to learn not only to position himself but also to identify with a socio-symbolic order was generated and authenticated in another continent, Europe. It could not be the mother tongue of people who were geographically (Algiers) and politically (as Jews) alienated from an assuredness of possible identifications with the French language. It is for this reason, because of a kind of double estrangement, that Derrida can claim, "I have only one language; it is not mine." And from this axiom follows and becomes understandable the title of the book, Monolingualism of the Other. The Other is the defining socio-symbolic order of France, the former colonial power in Algier where Derrida grew up. In Derrida's formulation: “...the monolingualism of the other would be that sovereignty, that law originating from elsewhere, certainly, but also primarily the very language of the Law. And the Law as Language"(39).

From the belief and experience of a totality in language (Steiner) to names as language fragments and fragmented memories the span of identificatory modalities (and their lack) reflects 20th century diasporic variations in and through language. Steiner's confidence in possessing several distinct identificatory modalities as a multilingual speaker and writer seems a kind of last testimony to an imaginary stability allocated to language and identity. Instead, multilinguality, as it may correspond with aspects of postmodern ethnicity, seems to imply an interaction between different languages with their distinct understanding of self and the world which manifests in a kaleidoscopic view, temporarily creating new constellations of 
Ethnic Studies Review Volume 23

meaning.

\section{Works Cited}

Anzaldua, Gloria. Borderlands La Frontera. San Francisco: Aunt Lute Books,1987.

Cixous, Hélène. Coming to Writing and Other Essays. Trans. D. Jenson, A. Liddle and S. Sellers. Cambridge/London: Harvard UP, 1991.

1994.

Derrida, Jacques. Monolingualism of the Other; or, The Prosthesis of Origin. Trans. Patrick Mensah. Stanford: Stanford UP, 1996.

Fishman, Joshua. Language \& Ethnicity in Minority Sociolinguistic Perspective. Clevedon/Philadelphia: Multilingual Matters Ltd., 1989.

Grosjean, François. Life with Two Languages. Cambridge, Massachusetts, and London: Harvard University Press, 1982.

Harshav, Benjamin. Language in Time of Revolution. Stanford: Stanford UP, 1993.

Heller, Celia. On the Edge of Destruction. New York: Columbia UP, 1977.

Klepfisz, Irena. "Secular Jewish Identity: Yidiskayt in America." The Tribe of Diana. Ed. Melanie/Kaye Kantrowitz and Irena Klepfisz. Boston: Beacon P, 1986.

Steiner, George. After Babel. Oxford/New York: Oxford UP, 1998.

Suleiman, Rubin Susan. "Monuments in a Foreign Tongue: On Reading Holocaust Memoirs by Emigrants." Exile and Creativity. Ed. Susan Rubin Suleiman. Durham/London: Duke UP, 1998.

\section{Endnotes}

1 Grosjean claims "Unlike bilingualism, where the two languages can be kept separate, biculturalism does not usually involve keeping two cultures and two individual behaviors separate. A true bicultural per- 
son, for instance, someone who is fully French in France and fully American in the United States, is probably not very common." (François Grosjean 1982 160)

2 In 1994/1995 forty-eight Jewish women were interviewed. See Livia Käthe Wittmann. Interactive Identities. Palmerston North: Dunmore, 1998.

3 Harshav notes the relevance of their adopted language for Jewish writers and cites Saul Bellow writing about Bernard Malamud: "Well, we were here, first-generation Americans, our language was English and a language is a spiritual mansion from which no one can evict us." (Harshav 1993, 21)

4 Yishuv: meaning "a stable settlement" as opposed to the "Exile" of the "Wandering Jew"; the new Jewish society that emerged in EretzIsrael before 1949 is called Yishuv (Harshav 1993, x).

5 And Fishman adds: "This leads to a kind of self-correction from within and from without, which extreme nationalism and racism do not permit" (18).

6 Fishman's observation regarding the imaginary nature of boundaries within and between collectivities also may function for the individual. "Boundaries," claims Fishman with reference to Barth, "whether between or within ethnic collectivities, are no more objective realities than are the ethnicity paternities, patrimonies or phenomenologies that they separate." (Fishman 1989, 34).

7 University entrance examination.

8 See Hoffman, 1991, 146-47.

9 Cixous adds "A deal was made: I would swallow only if I was given something to hear. Thirst of my ears. Blackmail for delights. While I was eating, incorporating, letting myself be force-fed, my head was enchanted, my thoughts escaped, my body here, my spirit on endless journeys" (Ibid.).

10 Kristeva, Julia. "From One Identity to an Other," Desire in Language. Ed. L.S. Roudiez. Columbia University Press: New York, 1980. 